\title{
Mulberry silk fabric treatment with natural colorants
}

\author{
Sathish, $\mathrm{P}^{1}$ and Jeyakodi Moses, $\mathrm{J}^{2 *}$ \\ \{atoms2020@gmail.com ${ }^{1}$,jjmoses2k2@gmail.com ${ }^{2}$ \} \\ ${ }^{1}$ Ph.D. Research Scholar, Research \& Development Centre, Bharathiar University, Coimbatore \\ 641046, India, ${ }^{2}$ Associate Professor, Department of Applied Science, PSG College of Technology, \\ Coimbatore 641004, India.
}

\begin{abstract}
Silk is the important versatile textile material being used for various delicate and formal enriched utilities. Traditionally for long period silk has been selected and colored with natural sources which would add values to the materials with respect to their original properties. Most of the natural sources have their inherent property add additional values to the silk materials. In this work the mulberry silk fabric is treated with recovered protein from sericin together with natural finishing sources like aloevera, amla and nochi in different combinations followed by coloring with few selected natural sources. The silk fabrics after these applications weresubjected for testing K/S value, fastness properties, absorbency, objective assessmentand SEM study. The results from these tests are impressive and positive suitable for the respective applications in the textile and garment utilities.
\end{abstract}

Keywords: Silk fabrics, natural sources, coloration, absorbency, sem.

\section{Introduction}

Theprotein based natural fibrous polymer, silkcontainsdifferent amino acids withfiber protein - fibroin $(75 \%)$ and a gummy non-filamentous protein, Sericin (25\%). The fiber protein-fibroin $\left(\mathrm{C}_{15} \mathrm{H}_{26} \mathrm{~N}_{5} \mathrm{O}_{6}\right)$ is the core for the fiber which is insoluble in hot water.The nonfibrous protein- sericin $\left(\mathrm{C}_{15} \mathrm{H}_{23} \mathrm{~N}_{5} \mathrm{O}_{6}\right)$ is a form of gum in the outer layer [1-3]. Silk is homogenous, hygroscopic, crystalline in nature, light in weight and the longest of all natural fibers [4-7]. Silk is superior towards comfort for high wearing, smooth feel to touch, lustrous to visibility, fine properties, required tensile strength, good appeal and aesthetic behaviorsrelevant for the quality, enriched fashioned garments and other end use products [8$11]$.

Silk is regarded as a symbol of royalty due to the lustrous appearance and peach-like softness. The specific gravity of silk filamentis of $1.250-1.300 \mathrm{~g} / \mathrm{cm}^{3}$ with the cross section shaped of triangular [10-14]. Mulberry silk filament has no scales on the outer layers; contains the tenacity of $0.38 \mathrm{~N} / \mathrm{Tex}$ and elongation at break of $23.4 \%$ in the test condition of $\mathrm{RH} 65 \%$ at $20^{\circ} \mathrm{C}$ [15-20]. The degummed silk with translucence \&smoothness is on the basis of the varied aspects of outward reflections on the surface, transmitted internal light, reflected internal light and light of diffusion [21-25].

As evidenced, the natural sources had been used elaborately for nearly 4000 years as colorants from plants with anti-insect properties involved for both herbal and coloring 
applications [26-28]. The developments in research activities towards natural colorgeneration and utilization is progressedwith respect to the widespreadimportance of natural lifestyle products based on eco-friendly sustainable process. Many plant origins were selected and used for the separation of extracts for coloring and the respective diversified application in the coloration and specific finishing of textile fiber substrates [29,30]. In this work raw silk fabric was selected and degummed for the removal of gum protein, sericin that was collected for the application along with the other natural sources like aloevera, amla, and nochi in different combinations followed by coloring with few listed eco-friendly sourcesnamely; madder, redsandal wood, barberry, annatto, myrobalan, pomogranate, onion, and grape. The results obtained from this work were convincing with respect to the suitability of utility in different textile and garment purposes.

\section{Experimental}

\subsection{Materials}

The raw silk fabric was purchased from the Sarvodhaya-Sangh, Coimbattore, Tamilnadu 641041. The fabric specifications of silk fabric are as: $2 / 80^{\mathrm{s}}$ for warp \&weft count respectively, 100 - ends/inch,60 - picks/inch, 95 - GSM, and 44 inch - cloth width. The Tamil Nadu Forest Department, Coimbatore 641043 (India) has supplied all the natural resources; i) madder, ii) red sandal wood, iii) barberry, iv) annatto, v) myrobalan, vi) pomogranate, vii) onion, and viii) grape are used for the coloration purposes; and ix) Aloevera, x) Amla, and Nochiare used for improved functional application purposes in addition to the protein (sericin) separated from raw silk fabric; separately and also in combined form on the silk fiber substrate with the coloring eco-friendly ingredients.AR grade is maintained for all the chemical items specified anywhere in this work.

\subsection{Methods}

2.2(i) Treatments on raw silk fabrics

The raw mulberry silk fabrics (plain, woven) were subjected by 10 gram per liter HClat ambient temperature for sixty min in a selected vessels of MLR (material-to-liquor ratio) $1 ; 30$ to remove the size impurities. After this, the fabrics were degummed using sodium carbonate ( $2 \%$ on weight of material (owm)) and commercial degum soap powder $\left(1 \%\right.$ owm) at $85^{\circ} \mathrm{C}$ for two hours. Finally, the degummed silk fabrics were washed thoroughly using de-ionized water and then dried [31-34].

\section{2(ii)Collection of protein from the degummed bath}

The remaining solution from the degummed bath is collected, separated and purified for the protein as per the established technique [35-39].

\section{2(iii)Preparation of the extracts}

The listed items for coloration namely madder, red sandal wood, barberry, annatto, myrobalan, pomogranate, onion, grape, aloevera, amla, and nochi are separated, purified and 
the extractionis carried out in the aqueous method as explained by the established technique $[40,41]$.

\section{2(iv)Coloration and determination of $\mathrm{k} / \mathrm{svalues}$ of dyed silk fabrics}

The coloration was performed using the extracted eco-friendly itemson the silk fiber substrate already treated with the following natural sources in different aspects for the enhancement of dyed and finished effect;

$\mathrm{o}$ - without any treatment ;n1 - with recovered protein ; n2- aloevera with protein

n3- amla with protein n4- nochi with protein

nI - Protein with (aloevera and amla); nII - Protein with (Aloevera and Nochi) nIIIProtein with (Amla and Nochi); nIV - Protein with (Aloevera, Amla and Nochi)

The coloration process was carried out on the silk fabrics with the conditions, such as: concentration $25 \mathrm{gpl}$, temperature $95^{\circ} \mathrm{C}$, time $2 \mathrm{~h}$, MLR 1:30based on the standard methods. The subsequentconcentration of [K/ S] color was studied by Kubelka - MunkRelation which describes the connection of spectral reflectance $(\mathrm{R})$ of sample and the respective absorption $(\mathrm{K})$ and the scattering $(\mathrm{S})$ characteristics; $\mathrm{K} / \mathrm{S}=\left((1-\mathrm{R})^{2} / 2 \mathrm{R}\right)[42-44]$.

\section{2(v)Fastnessproperty measurement}

The washing of eco-friendly colored silk fabrics were based on thetest method conditions of AATCC 135-1985, 2003 \& AATCC 61-1996, 2003 to achieve the effect in the color change. Light fastness and staining fastnesstests were also carried out by AATCCconditions [45-47].

\section{2(vi) Theabsorbency behavior}

The absorbency characters of natural colored silk fabrics was measured as per the established AATCC - 79-2010; ASTM E96and ASTM D737 test methods [48-51].

\section{2(vii)Objectiveassessment on natural colored silk fabricsby KES-F}

The hand value characters of the natural colored silk fiber substrates were assessed by thetechnique of KES-F [52].

\section{2(viii)SEMstudy on natural colored silk fabrics}

The natural colored silk fabrics were analyzed for SEM study from 30-kV JEOL (Japan) Model, JSM-6360scanning electron microscope[53, 54].

\section{Results and discussion}

3.1. Natural coloration assessment study

3.1(i) Naturalcoloration and measurement of $\mathrm{k} / \mathrm{s}$ values of the silk fabrics 
The coloration process using the eco-friendly natural itemsis applied on silk fiber substrates which is treated already with selected finishing sources like aloevera, amla, nochi and recovered protein in the intact as well as in the combined form. The data obtained related to this type of application is presentedin the Table 1(i). From this, it is understood, the silk fabric gets good color in the range of red, orange red, yellow, orange, green, brown, red orange and purple when colored with the help of eco-friendly natural items. The data of k/s values are increased with the increase of treatment on silk fabrics using the finishing type of natural sources such as aloevera, amla, nochi and recovered protein. There is an increased data of $\mathrm{k} / \mathrm{s}$ for the silk fabric treated by recovered protein with aloevera, amla and nochi followed by colored with natural sources (nIV, nII, nI and nIII). When the silk fabricis treated with recovered protein and one of the natural finishing sources (aloevera, amla, nochi) followed by coloration with natural coloring sources, $\mathrm{k} / \mathrm{s}$ values are reduced in the normal manner (n2, n4, n3, n1). The k/s value is least for the silk fabric without any finishing natural source treatment, however only colored with the natural coloring sources (o).

Table 1(i). Natural coloration and measurement of k/s

\begin{tabular}{|c|c|c|c|c|c|c|c|c|c|c|c|}
\hline \multirow{2}{*}{$\begin{array}{l}\text { S. } \\
\text { No. }\end{array}$} & \multirow{2}{*}{$\begin{array}{l}\text { Natural sources } \\
\text { (Botanical name) }\end{array}$} & \multirow{2}{*}{$\begin{array}{l}\text { Colors } \\
\text { obtained }\end{array}$} & \multicolumn{9}{|c|}{$\mathrm{k} / \mathrm{s}$ of the natural colored silk fiber substrates } \\
\hline & & & $\mathrm{O}$ & $\mathrm{n} 1$ & $\mathrm{n} 2$ & n3 & $\mathrm{n} 4$ & nI & nII & nIII & nIV \\
\hline 1 & $\begin{array}{l}\text { Madder } \\
\text { (Rubiacardifolia) }\end{array}$ & Red & 12.7 & 12.8 & 13.3 & 13.0 & 13.2 & 13.5 & 13.4 & 13.4 & 13.6 \\
\hline 2 & $\begin{array}{ll}\mathrm{RS} & \text { Wood } \\
\text { (Pterocarpussantallinus) }\end{array}$ & $\begin{array}{l}\text { Orange } \\
\text { Red }\end{array}$ & 12.6 & 12.9 & 13.4 & 13.1 & 13.3 & 13.6 & 13.7 & 13.5 & 13.8 \\
\hline 3 & $\begin{array}{l}\text { Barberry } \\
\text { vulgaris) }\end{array}$ & Yellow & 12.7 & 12.9 & 13.5 & 13.2 & 13.3 & 13.6 & 13.7 & 13.6 & 13.8 \\
\hline 4 & $\begin{array}{l}\text { Annatto } \\
\text { (Bixaorellana) }\end{array}$ & Orange & 13.0 & 13.1 & 13.5 & 13.2 & 13.4 & 13.7 & 13.7 & 13.6 & 13.9 \\
\hline 5 & $\begin{array}{l}\text { Myrobalan } \\
\text { (Terminaliachebula) }\end{array}$ & Green & 12.4 & 12.7 & 13.3 & 12.9 & 13.1 & 13.6 & 13.7 & 13.5 & 13.8 \\
\hline 6 & $\begin{array}{l}\text { Pomogranate } \\
\text { (Punicagranatum) }\end{array}$ & Brown & 12.9 & 13.2 & 13.6 & 13.3 & 13.5 & 13.7 & 13.8 & 13.7 & 13.9 \\
\hline 7 & $\begin{array}{l}\text { Onion } \\
\text { (Allium cepa) }\end{array}$ & $\begin{array}{l}\text { Red } \\
\text { Orange }\end{array}$ & 12.8 & 12.9 & 13.4 & 13.1 & 13.3 & 13.6 & 13.7 & 13.5 & 13.8 \\
\hline 8 & $\begin{array}{l}\text { Grape } \\
\text { (Citrus paradise) }\end{array}$ & Purple & 12.5 & 12.7 & 13.4 & 12.9 & 13.1 & 13.5 & 13.7 & 13.4 & 13.8 \\
\hline
\end{tabular}

RS Wood $\rightarrow$ Red sandal wood $\mathrm{o}$ - without any treatment ;n1 - with recovered protein ; n2- aloevera with protein n3- amla with protein n4- nochi with protein

nI - Protein with (aloevera and amla); nII - Protein with (Aloevera and Nochi) nIII-

Protein with (Amla and Nochi); nIV - Protein with (Aloevera, Amla and Nochi)

\section{1(ii)Fastnessproperty measurement of natural colored silk fabrics}


The data of the fastness property (wash, light and stain) of the natural colored silk fabrics colored using the eco-friendly natural items treated already with selected finishing sources like aloevera, amla, nochi and recovered protein in the intact as well as in the combined form are presented in the Table 1(ii). From this, it is indicated that the fastness property of the natural colored silk fabric treated with the finishing natural sources in different combinations is good in general. There is a good to very good fatness property rating (3-4) for the natural colored silk fabric subjected with the recovered protein together with aloevera, amla, and nochi in different combined form. The fastness property is moderate to good (3) for the natural colored silk fabric treated already with the recovered protein with withaloevera, amla, and nochi separately. The natural colored silk fabric without any finishing sources treatment shows only poor to moderate (2-3) fastness property.

Table1(ii). Fastness property measurement of natural colored silk fabrics

\begin{tabular}{|c|c|c|c|c|c|c|c|c|c|c|c|c|c|c|c|c|}
\hline \multirow{2}{*}{$\begin{array}{l}\text { S. } \\
\text { No. }\end{array}$} & \multirow{2}{*}{ Dyes } & \multicolumn{5}{|c|}{ Wash fastness } & \multicolumn{5}{|c|}{ Light fastness } & \multicolumn{5}{|c|}{ Stain fastness } \\
\hline & & 0 & $\mathrm{n} 1$ & $\mathrm{n} 2$ & n3 & $\mathrm{n} 4$ & o & \begin{tabular}{l|l}
$\mathrm{n} 1$ \\
\end{tabular} & n2 & n3 & $\mathrm{n} 4$ & o & $\mathrm{n} 1$ & $\mathrm{n} 2$ & $\mathrm{n} 3$ & $\mathrm{n} 4$ \\
\hline 1 & Madder & $2-3$ & 3 & $3-4$ & $3-4$ & $3-4$ & $3-4$ & $3-4$ & 4 & 4 & 4 & $2-3$ & $2-3$ & 3 & 3 & 3 \\
\hline 2 & RS wood & $2-3$ & 3 & 3 & 3 & 3 & 3 & $3-4$ & $3-4$ & $3-4$ & $3-4$ & 2 & $2-3$ & $2-3$ & $2-3$ & $2-3$ \\
\hline 3 & Barberry & 3 & 3 & $3-4$ & 3 & 3 & $3-4$ & 4 & 4 & 4 & 4 & $2-3$ & $2-3$ & 3 & $2-3$ & 3 \\
\hline 4 & Annatto & $2-3$ & 3 & $3-4$ & 3 & $3-4$ & $3-4$ & $3-4$ & 4 & $3-4$ & 4 & 3 & 3 & 3 & 3 & 3 \\
\hline 5 & Myrobalan & 3 & $3-4$ & $3-4$ & $3-4$ & $3-4$ & $3-4$ & 4 & 4 & 4 & 4 & 3 & 3 & 3 & 3 & 3 \\
\hline 6 & Pomogranate & 3 & $3-4$ & $3-4$ & $3-4$ & $3-4$ & $3-4$ & $3-4$ & 4 & 4 & 4 & $2-3$ & 3 & 3 & 3 & 3 \\
\hline 7 & Onion & 3 & 3 & 3 & 3 & 3 & 3 & $3-4$ & 4 & $3-4$ & $3-4$ & $2-3$ & $2-3$ & 3 & $2-3$ & $2-3$ \\
\hline 8 & Grape & $2-3$ & 3 & 3 & 3 & 3 & 3 & $3-4$ & $3-4$ & $3-4$ & $3-4$ & 2 & $2-3$ & $2-3$ & $2-3$ & $2-3$ \\
\hline \multirow{2}{*}{$\begin{array}{l}\text { S. } \\
\text { No. }\end{array}$} & \multirow{2}{*}{ Dyes } & \multicolumn{5}{|c|}{ Wash fastness } & \multicolumn{5}{|c|}{ Light fastness } & \multicolumn{5}{|c|}{ Stain fastness } \\
\hline & & $\mathrm{nI}$ & & & $\mathrm{nIII}$ & $\mathrm{nIV}$ & $\mathrm{nI}$ & nII & & nIII & nIV & $\mathrm{nI}$ & $\mathrm{nIl}$ & & nIII & $\mathrm{nIV}$ \\
\hline 1 & Madder & $3-4$ & & & 3 & $3-4$ & 4 & 4 & & 4 & $4-5$ & 3 & 3 & & 3 & $3-4$ \\
\hline 2 & RS wood & 3 & 3 & & 3 & $3-4$ & $3-4$ & 4 & & $3-4$ & 4 & $2-3$ & 3 & & $2-3$ & 3 \\
\hline 3 & Barberry & 3 & & & 3 & $3-4$ & 4 & 4 & & 4 & 4 & 3 & 3 & & 3 & $3-4$ \\
\hline 4 & Annatto & $3-4$ & & & $3-4$ & 4 & 4 & $4-5$ & & 4 & $4-5$ & 3 & 3 & & 3 & $3-4$ \\
\hline 5 & Myrobalan & $3-4$ & & & $3-4$ & $3-4$ & 4 & 4 & & $3-4$ & $4-5$ & 3 & $3-2$ & & 3 & $3-4$ \\
\hline 6 & Pomogranate & $3-4$ & & & $3-4$ & 4 & 4 & $4-5$ & & 4 & $4-5$ & 3 & $3-2$ & & 3 & $3-4$ \\
\hline 7 & Onion & 3 & 3 & & 3 & $3-4$ & 4 & 4 & & $3-4$ & 4 & 3 & 3 & & $2-3$ & 3 \\
\hline 8 & Grape & 3 & 3 & & 3 & 3 & $3-4$ & $3-4$ & & $3-4$ & 4 & $2-3$ & $2-3$ & & $2-3$ & 3 \\
\hline
\end{tabular}

\subsection{Absorption study}

The values of WR,WVP and APof silk fabric treated with selected finishing sources like aloevera, amla, nochi and recovered protein in the intact as well as in the combined form and colored using the eco-friendly natural items are presented in the table 2. As evidenced in this table 2, there is a direct relationship between the WR and WVP\&APof natural colored silk fabric. The WVP and APbehavior is more on the treated and dyed silk fabric with respect to the relative increase of the WR. Accordingly, the increase of WR and WVP\&AP are proceeded with the increase of treatment on silk fabrics using the finishing type of natural 
sources such as aloevera, amla, nochi and recovered protein. The increase is maximum for the silk fabric treated by recovered protein with aloevera, amla and nochi followed by colored with natural sources (nIV, nII, nI and nIII). There is a marginal decrease in the WR andWVP\&APbehaviors on the other treated and colored silk fabrics $(n 2, n 4, n 3, n 1)$. These values are least for the colored silk fabrics without any finishing treatments (o).

Table 2. WR, WVP \& AP of thenatural colored silk fabrics

\begin{tabular}{|c|c|c|c|c|c|c|c|c|c|c|}
\hline \multirow{2}{*}{$\begin{array}{l}\text { S. } \\
\text { No. }\end{array}$} & \multirow{2}{*}{ Dyes } & \multicolumn{9}{|c|}{ Water retention, WR (\%) } \\
\hline & & o & n1 & $\mathrm{n} 2$ & n3 & $\mathrm{n} 4$ & $\mathrm{nI}$ & $\mathrm{nII}$ & nIII & nIV \\
\hline 0 & No Dye & 202 & 224 & 243 & 235 & 238 & 249 & 253 & 245 & 257 \\
\hline 1 & Madder & 204 & 227 & 245 & 238 & 242 & 252 & 256 & 248 & 259 \\
\hline 2 & Red sandal wood & 205 & 229 & 246 & 237 & 244 & 253 & 255 & 248 & 260 \\
\hline 3 & Barberry & 204 & 229 & 245 & 238 & 243 & 251 & 255 & 247 & 259 \\
\hline 4 & Annatto & 206 & 228 & 246 & 238 & 242 & 252 & 256 & 249 & 260 \\
\hline 5 & Myrobalan & 205 & 228 & 245 & 237 & 242 & 252 & 255 & 248 & 261 \\
\hline 6 & Pomogranate & 206 & 229 & 246 & 238 & 243 & 253 & 257 & 248 & 260 \\
\hline 7 & Onion & 204 & 227 & 245 & 237 & 242 & 252 & 256 & 249 & 260 \\
\hline 8 & Grape & 207 & 228 & 245 & 237 & 243 & 252 & 255 & 248 & 259 \\
\hline \multirow{2}{*}{ S. No. } & \multirow{2}{*}{ Dyes } & \multicolumn{9}{|c|}{ Water vapor permeability, WVP (g/m2/day) } \\
\hline & & o & $\mathrm{n} 1$ & $\mathrm{n} 2$ & n3 & $\mathrm{n} 4$ & $\mathrm{nI}$ & $\mathrm{nII}$ & nIII & nIV \\
\hline 0 & No Dye & 1578 & 1655 & 1685 & 1667 & 1675 & 1697 & 1704 & 1690 & 1714 \\
\hline 1 & Madder & 1612 & 1690 & 1725 & 1705 & 1713 & 1740 & 1748 & 1732 & 1760 \\
\hline 2 & Red sandal wood & 1618 & 1696 & 1727 & 1708 & 1716 & 1739 & 1747 & 1732 & 1760 \\
\hline 3 & Barberry & 1620 & 1698 & 1729 & 1710 & 1720 & 1743 & 1750 & 1735 & 1762 \\
\hline 4 & Annatto & 1620 & 1698 & 1730 & 1712 & 1719 & 1742 & 1751 & 1735 & 1762 \\
\hline 5 & Myrobalan & 1618 & 1697 & 1732 & 1711 & 1720 & 1744 & 1751 & 1736 & 1763 \\
\hline 6 & Pomogranate & 1620 & 1695 & 1728 & 1708 & 1717 & 1742 & 1750 & 1734 & 1762 \\
\hline 7 & Onion & 1620 & 1697 & 1731 & 1712 & 1720 & 1743 & 1751 & 1736 & 1763 \\
\hline 8 & Grape & 1619 & 1698 & 1730 & 1710 & 1719 & 1742 & 1750 & 1736 & 1762 \\
\hline \multirow{2}{*}{ S. No. } & \multirow{2}{*}{ Dyes } & \multicolumn{9}{|c|}{ Air permeability, AP (1/min) } \\
\hline & & o & $\mathrm{n} 1$ & $\mathrm{n} 2$ & n3 & $\mathrm{n} 4$ & $\mathrm{nI}$ & $\mathrm{nII}$ & nIII & nIV \\
\hline 0 & No Dye & 72 & 75 & 93 & 82 & 87 & 98 & 102 & 95 & 106 \\
\hline
\end{tabular}




\begin{tabular}{|l|l|l|l|l|l|l|l|l|l|l|}
\hline 1 & Madder & 78 & 85 & 105 & 93 & 98 & 113 & 118 & 109 & 126 \\
\hline 2 & Red sandal wood & 78 & 86 & 105 & 94 & 99 & 114 & 118 & 109 & 125 \\
\hline 3 & Barberry & 79 & 86 & 106 & 93 & 99 & 114 & 119 & 110 & 124 \\
\hline 4 & Annatto & 81 & 88 & 105 & 94 & 99 & 115 & 120 & 110 & 125 \\
\hline 5 & Myrobalan & 80 & 86 & 106 & 93 & 98 & 113 & 118 & 109 & 125 \\
\hline 6 & Pomogranate & 79 & 86 & 107 & 94 & 100 & 115 & 119 & 111 & 124 \\
\hline 7 & Onion & 80 & 88 & 106 & 95 & 100 & 116 & 120 & 111 & 126 \\
\hline 8 & Grape & 80 & 87 & 105 & 94 & 99 & 115 & 120 & 110 & 125 \\
\hline
\end{tabular}

\subsection{Objective assessment study byKES-F}

The surface properties of natural colored silk fabrics are presented in Table 3(i), 3(ii) and 3(iii) based on the standard description as given in Table 3. From the Table 3(i) which gives the details regarding the smoothness, stiffness and fullness of the natural colored silk fabric. From this table it is shown that as the combination of finishing treatment using recovered protein with other natural finishing sources increases, in different combined form the smoothness and fullness increases and stiffness decreases correspondingly after coloration with natural sources compared with those of the untreated natural colored silk fabric. Similarly from the Tables 3(ii) and 3(iii) the bending length and crease recovery are decreased correspondingly with the increase of finishing source treatments using the recovered protein with other sources like aloevera, amla, and nochi in different combined forms followed by coloring with the natural sources.

Table3. Standard description for surface properties from KES-F

\begin{tabular}{|l|}
\hline Description with unit \\
\hline${ }^{\text {a }}$ Tensile \\
\hline LT:Load/extension Linearity curve [None] \\
\hline WT:Tensile energy [N/m] \\
\hline RT:Tensile resilience [\%] \\
\hline${ }^{\text {a Bending }}$ \\
\hline B:Bending rigidity $\left[10^{-4} \mathrm{Nm}\right]$ \\
\hline HB:Hysteresis of bending moment $\left[10^{-2} \mathrm{~N}\right]$ \\
\hline${ }^{\text {a }}$ Shearing \\
\hline G:Shear stiffness [N/m Deg.] \\
\hline HG:Hysteresis of shear force at $0.5^{\circ}$ of shear angle $[\mathrm{N} / \mathrm{m}]$ \\
\hline HG5:Hysteresis of shear force at $5^{\circ}$ of shear angle $[\mathrm{N} / \mathrm{m}]$ \\
\hline Compression \\
\hline LC:Linearity of compression/thickness curve [None] \\
\hline WC:Compressional energy [N/m] \\
\hline
\end{tabular}




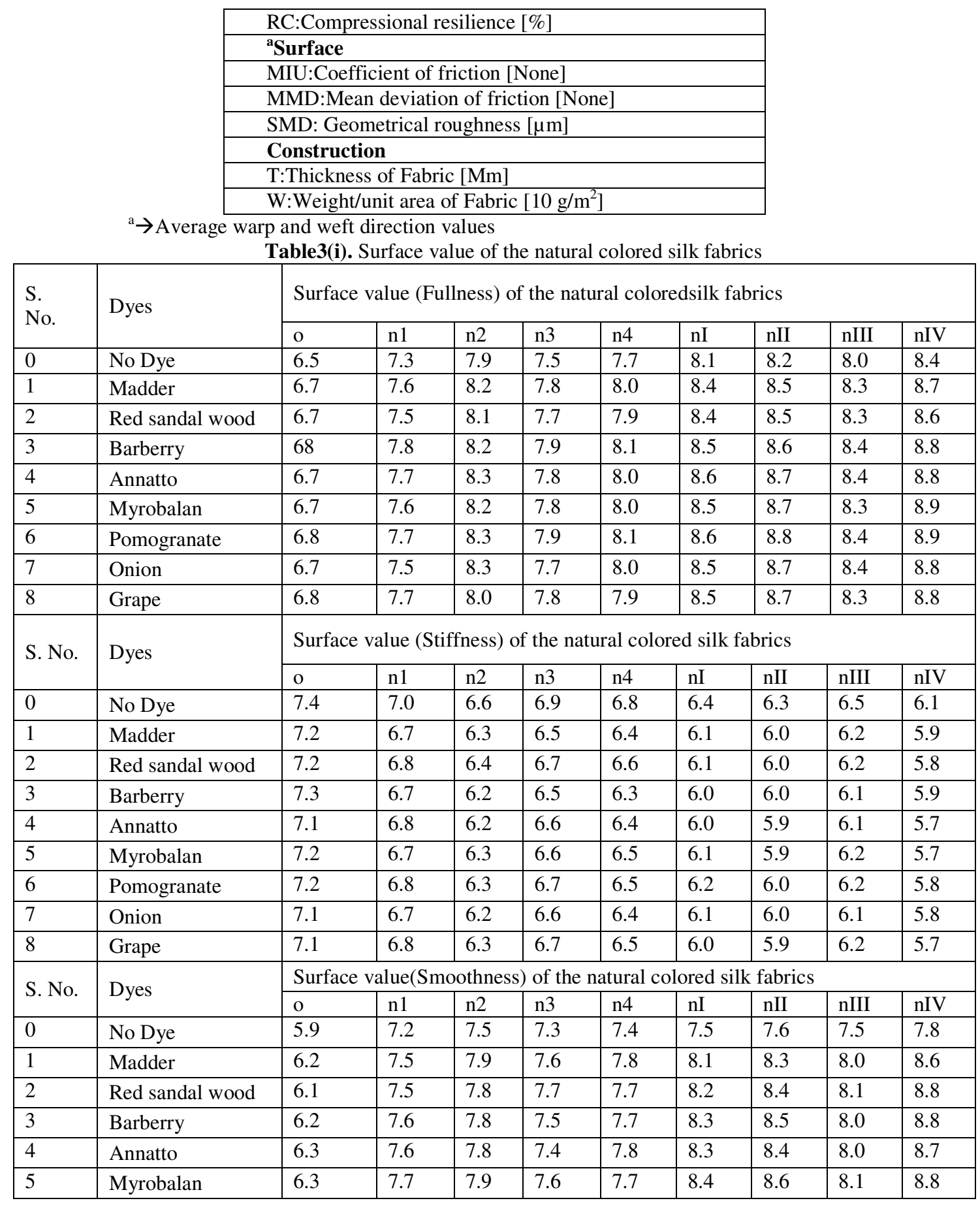




\begin{tabular}{|l|l|l|l|l|l|l|l|l|l|l|}
\hline 6 & Pomogranate & 6.2 & 7.7 & 8.0 & 7.7 & 7.8 & 8.4 & 8.6 & 8.2 & 8.8 \\
\hline 7 & Onion & 6.1 & 7.5 & 7.8 & 7.6 & 7.7 & 8.3 & 8.4 & 8.1 & 8.7 \\
\hline 8 & Grape & 6.1 & 7.5 & 7.8 & 7.6 & 7.7 & 8.2 & 8.3 & 8.0 & 8.6 \\
\hline
\end{tabular}

Table3(ii). BL values of the natural colored silk fabrics

\begin{tabular}{|c|c|c|c|c|c|c|c|c|c|c|}
\hline \multirow{2}{*}{$\begin{array}{l}\text { S. } \\
\text { No. }\end{array}$} & \multirow{2}{*}{ Dyes } & \multicolumn{9}{|c|}{$\mathrm{BL}(\mathrm{mm})$ of the natural colored silk fabrics [Warp $(\mathrm{Cw})]$} \\
\hline & & $\mathrm{O}$ & $\mathrm{n} 1$ & $\mathrm{n} 2$ & n3 & $\mathrm{n} 4$ & $\mathrm{nI}$ & nII & nIII & nIV \\
\hline 0 & No Dye & 10.4 & 10.0 & 9.7 & 09.9 & 09.8 & 09.5 & 09.4 & 09.6 & 09.3 \\
\hline 1 & Madder & 10.2 & 09.8 & 09.3 & 09.6 & 09.5 & 09.0 & 08.8 & 09.2 & 08.5 \\
\hline 2 & Red sandal wood & 10.1 & 09.7 & 09.3 & 09.6 & 09.5 & 09.1 & 08.9 & 09.2 & 08.3 \\
\hline 3 & Barberry & 10.3 & 09.8 & 09.4 & 09.7 & 09.5 & 09.1 & 08.9 & 09.3 & 08.6 \\
\hline 4 & Annatto & 10.2 & 09.8 & 09.3 & 09.6 & 09.4 & 09.1 & 09.0 & 09.2 & 08.8 \\
\hline 5 & Myrobalan & 10.1 & 09.8 & 09.3 & 09.6 & 09.5 & 09.0 & 08.8 & 09.2 & 08.6 \\
\hline 6 & Pomogranate & 10.3 & 09.7 & 09.3 & 09.5 & 09.4 & 09.1 & 08.9 & 09.2 & 08.6 \\
\hline 7 & Onion & 10.3 & 09.8 & 09.4 & 09.6 & 09.5 & 09.2 & 09.0 & 09.3 & 08.7 \\
\hline 8 & Grape & 10.2 & 09.7 & 09.4 & 09.6 & 09.5 & 09.1 & 08.9 & 09.3 & 08.7 \\
\hline \multirow{2}{*}{ S. No. } & \multirow{2}{*}{ Dyes } & \multicolumn{9}{|c|}{$\mathrm{BL}(\mathrm{mm})$ of the natural colored silk fabrics [Weft $(\mathrm{Cf})]$} \\
\hline & & o & $\mathrm{n} 1$ & $\mathrm{n} 2$ & $\mathrm{n} 3$ & $\mathrm{n} 4$ & $\mathrm{nI}$ & nII & nIII & nIV \\
\hline 0 & No Dye & 10.2 & 09.7 & 09.4 & 09.6 & 09.5 & 09.2 & 09.2 & 09.3 & 09.1 \\
\hline 1 & Madder & 09.9 & 09.4 & 08.8 & 09.2 & 09.0 & 08.7 & 08.5 & 08.9 & 08.4 \\
\hline 2 & Red sandal wood & 10.0 & 09.3 & 08.9 & 09.2 & 09.1 & 08.7 & 08.6 & 08.8 & 08.4 \\
\hline 3 & Barberry & 09.9 & 09.4 & 08.8 & 09.2 & 09.0 & 08.8 & 08.5 & 08.9 & 08.3 \\
\hline 4 & Annatto & 09.8 & 09.3 & 08.9 & 09.1 & 09.0 & 08.7 & 08.6 & 08.8 & 08.4 \\
\hline 5 & Myrobalan & 09.9 & 09.4 & 08.8 & 09.2 & 09.1 & 08.7 & 08.5 & 08.9 & 08.3 \\
\hline 6 & Pomogranate & 10.0 & 09.4 & 08.8 & 09.1 & 09.0 & 08.8 & 08.6 & 08.9 & 08.4 \\
\hline 7 & Onion & 09.9 & 09.3 & 08.9 & 09.2 & 09.1 & 08.7 & 08.5 & 08.8 & 08.5 \\
\hline 8 & Grape & 09.9 & 09.4 & 08.9 & 09.2 & 09.1 & 08.7 & 08.6 & 08.8 & 08.4 \\
\hline
\end{tabular}

$\mathrm{BL} \rightarrow$ Bending Length

Table3(iii). CR values of the natural colored silk fabrics

\begin{tabular}{|l|l|l|l|l|l|l|l|l|l|l|}
\hline \multirow{2}{*}{$\begin{array}{l}\text { S. } \\
\text { No. }\end{array}$} & \multirow{2}{*}{ Dyes } & \multicolumn{9}{|c|}{ CR $\left(^{\circ}\right)$ of the natural colored silk fabrics [Warp $\left.(\mathrm{Cw})\right]$} \\
\cline { 3 - 12 } & & o & n1 & n2 & n3 & n4 & nI & nII & nIII & nIV \\
\hline 0 & No Dye & 117 & 114 & 110 & 113 & 112 & 108 & 107 & 109 & 106 \\
\hline 1 & Madder & 113 & 111 & 106 & 109 & 108 & 105 & 104 & 106 & 103 \\
\hline 2 & Red sandal wood & 115 & 111 & 107 & 110 & 109 & 104 & 103 & 106 & 103 \\
\hline 3 & Barberry & 114 & 110 & 105 & 109 & 107 & 103 & 103 & 104 & 102 \\
\hline 4 & Annatto & 114 & 111 & 107 & 110 & 109 & 104 & 104 & 106 & 103 \\
\hline 5 & Myrobalan & 115 & 112 & 108 & 111 & 110 & 105 & 104 & 107 & 103 \\
\hline 6 & Pomogranate & 113 & 111 & 107 & 110 & 109 & 105 & 104 & 105 & 102 \\
\hline 7 & Onion & 115 & 112 & 106 & 111 & 108 & 104 & 103 & 106 & 102 \\
\hline
\end{tabular}




\begin{tabular}{|c|c|c|c|c|c|c|c|c|c|c|}
\hline 8 & Grape & 114 & 112 & 107 & 110 & 109 & 105 & 104 & 106 & 103 \\
\hline \multirow{2}{*}{$\begin{array}{l}\text { S. } \\
\text { No. }\end{array}$} & \multirow{2}{*}{ Dyes } & \multicolumn{9}{|c|}{$\mathrm{CR}\left({ }^{\circ}\right)$ of the natural colored silk fabrics [Weft $\left.(\mathrm{Cf})\right]$} \\
\hline & & 0 & $\mathrm{n} 1$ & n2 & n3 & $\mathrm{n} 4$ & $\mathrm{nI}$ & nII & nIII & nIV \\
\hline 0 & No Dye & 113 & 112 & 109 & 111 & 110 & 107 & 106 & 108 & 104 \\
\hline 1 & Madder & 111 & 109 & 104 & 108 & 106 & 102 & 100 & 103 & 98 \\
\hline 2 & Red sandal wood & 109 & 108 & 104 & 107 & 105 & 102 & 101 & 103 & 99 \\
\hline 3 & Barberry & 110 & 109 & 103 & 106 & 105 & 101 & 100 & 102 & 98 \\
\hline 4 & Annatto & 110 & 108 & 104 & 107 & 106 & 102 & 101 & 103 & 98 \\
\hline 5 & Myrobalan & 109 & 108 & 103 & 106 & 105 & 101 & 100 & 102 & 99 \\
\hline 6 & Pomogranate & 110 & 109 & 104 & 107 & 106 & 102 & 100 & 103 & 98 \\
\hline 7 & Onion & 111 & 108 & 103 & 106 & 105 & 101 & 100 & 102 & 99 \\
\hline 8 & Grape & 109 & 108 & 103 & 106 & 105 & 102 & 101 & 103 & 98 \\
\hline
\end{tabular}

\section{$\mathrm{CR} \rightarrow$ Crease recovery}

\subsection{Surface morphology study bySEM}

The SEM images of representative silk fabrics are only shown in Figure 1. The degummed silk fabric (1(a)), the annatto colored silk fabric (1(b)), the recovered protein treated and annatto colored silk fabric (1(c)), the recovered protein (with aloevera) treated and annatto colored silk fabric (1(d)), the recovered protein (with aloevera and nochi) treated and annatto colored silk fabric (1(e)), and the recovered protein (with aloevera, amla and nochi) treated and annatto colored silk fabric (1(f)) are the respective samples given in Figure 1. From these figures it is clear that as the finishing source treatments (recovered protein, aloevera, nochi and amla) increases the effect on the silk fabric also increases. The increased finishing effect is seen in the SEM images in the case of the silk fabric subjected with recovered protein , aloevera and nochi (1(e)); and recovered protein, aloevera, amla and nochi (1(f)) followed by coloring with annatto.

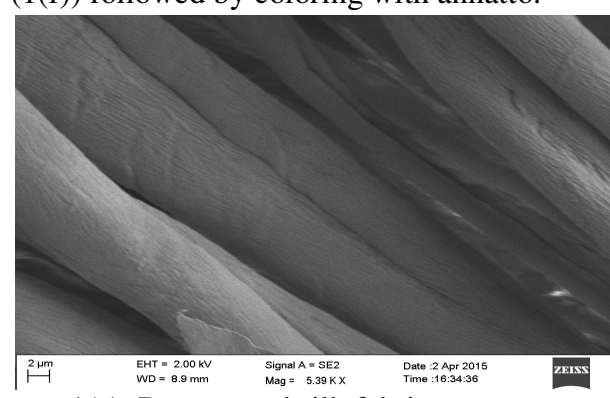

1(a). Degummed silk fabric

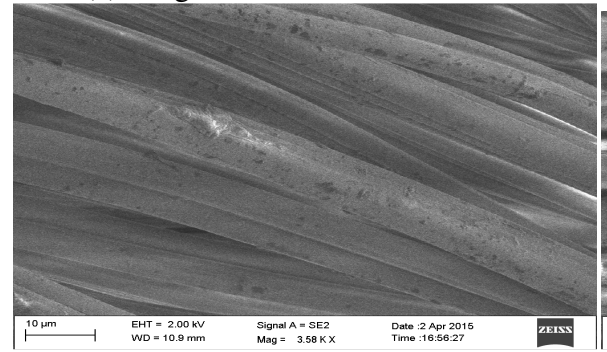

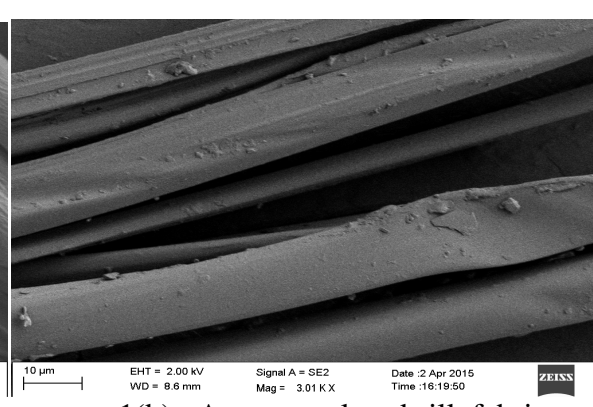

1(b). Annatto colored silk fabric

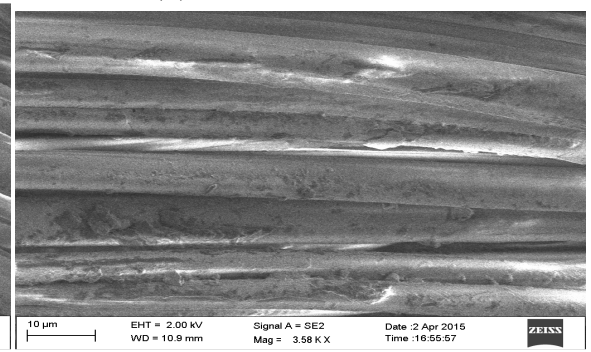


1(c). Recovered protein treated and annatto 1(d). Recovered protein (with aloevera) coloredsilk fabric treated and annatto colored silk fabric

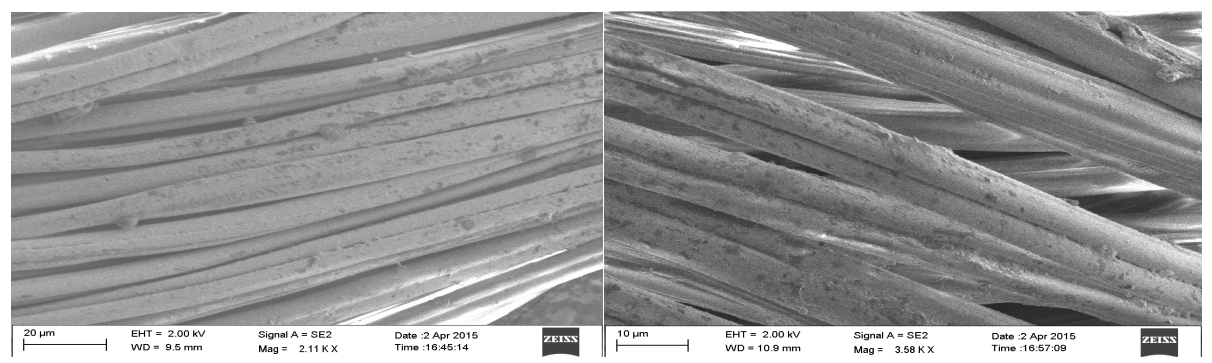

1(e). Recovered protein (with aloevera and

1(f). Recovered protein (with aloevera, amla

nochi)treated and annatto colored

silkfabricsilk fabric

and nochi) treated and annatto colored

Figure 1. SEM images of silk fabrics

\section{Conclusion}

The $\mathrm{k} / \mathrm{s}$ values are increased with the increase of treatment using the finishing type of natural sources such as aloevera, amla, nochi and recovered protein on silk fabrics and colored with natural sources. The increase of $\mathrm{k} / \mathrm{s}$ value is maximum for the silk fabric treated by recovered protein with aloevera, amla and nochi followed by colored with natural sources. There is a good to very good fatness property rating for the natural colored silk fabric subjected with the recovered protein together with aloevera, amla, and nochi in different combined form. The fastness property is moderate to good for the silk fabric treated with the recovered protein with aloevera, amla, and nochi separately and colored with natural sources.

The increase of water retention, water vapor and air permeability are proceeded with the increase of treatment on silk fabrics using the finishing type of natural sources such as aloevera, amla, nochi and recovered protein. The air permeability is in accordance with the behavior of the water vapor permeability of the silk fabric. By the way, the water vapor permeability and air permeability value are maximum for silk fabrics treated with finishing type of natural sources such as aloevera, amla, nochi and recovered protein followed by colored with natural sources.

The mechanical and surface properties of silk fabrics treated with the recovered protein with aloevera, amla, and nochi and colored with natural sources are in the suitable uniform trend. The increased finishing effect is seen in the SEM images in the case of the silk fabric subjected with recovered protein, aloevera and nochi; and recovered protein, aloevera, amla and nochi followed by coloring.

\section{Acknowledgement}


The researchers extend their gratitude to the Principal\& theManagement, PSGCT, Coimbatore for the permission given and handling the instruments and apparatus.Sincere thanks are also extended to the Head-of-Department, AppliedScience, PSGCT.

\section{References}

[1] D.Kaplan,W.W. Adams,B. Farmer,C. Viney, Silk polymers materials science and Biotechnology Chapter 1, American Chemical Society, Washington, 1993.

[2] N. Hojo, Structure of silk yarn - Part A, Biological and physical aspects, Science Publishers, USA. 2000.

[3] M.L. Gulrajani, R.P.Prasad, R. Kamal, M.J.Joshi, Studies on structural \& functional properties of sericin covered from silk degumming liquor by membranetechnology, App. Poly. Sci.113(2009), 2796-2804.

[4] G.H.Altman,F. Diaz, C. Jakuba,T. Calabro,R.L.Horan. et al. Silk based biomaterials, Biomaterials, 24(3)(2003), 401-416.

[5] N. Amiraliyan,M. Nouri,M. Haghighat, Structural characterization and mechanicalproperties of electrospun silk fibroin nanofiber mats, Poly.Sci. Series A, 52(2010),407-412.

[6] K. Sen,M.K. Babu, Studies on indian silk- I:Macrocharacterization and analysis of amino acid composition, J. App. Poly. Sci. 92(2004), 1080-1097.

[7] T. Asakura, T. Yamare, Y. Nakazawa,T. Kamada,K. And ,Structure of bombyxmori silk fibroin before spinning in solid state studied with wide angle $\mathrm{x}$-ray scatteringand13crosspolarization/magicanglespinningNMR,Biopolymers, 58(2001), 521-525.,

[8] N. Reddy,Y. Yang,Investigation of the structure and properties of silk fibersproduced by actiaslunas, J. Poly.\&Env.20(2012), 659-664.

[9] X. Chen X,D.P.Knight, Z. Shao,F. Vollrath, Regenerated bombyxmori solution studied with rheometry\& FTIR, Polymer, 42(2001), 9969-9974.

[10] S.W. Ha,A.E. Tonelli, S.M. Hudson,Structural studies of bombyxmori silk fibroin during regeneration from solution and wet fiber spinning, Biomacromolecules, 6(2005), 1722-1731.

[11] K. Sen,M.K. Babu,Studies on Indian silk- II: Structure property correlations, J. of App. Poly. Sci. 92(2004), 1098-1115.

[12] I.C.Um, C.S. Ki, H.Y.Kweon, K.G. Lee,D.W.Ihm, et al. Silk polymer- II: Effect of drawing on the structural characteristic \& properties of filament. Intl. J.Biol. Macromolecule, 34(2004),107-109.

[13] K. Komatsu,SilkIII.Sericinphysicalstructure.Sericologia, 22(1982), 14-23.

[14] T. Konishi,Structureoffibroin-ainstructureofsilkyarn;N. Hojo.(ed)OxfordandIBHPublication Co. Pvt. Ltd, NewDelhi, 2000,267-277.

[15] R.M. Robson,Silkcomposition,structureandproperties;inHandbookoffibrescienceandtechnology Vol IV,M. Lewin,E.M. Pearce.(ed),MercelDekkerInc. NewYork, 1985,649-700.

[16] M. Shimizu,Structuralbasisofsilkfibre;inStructureofsilkyarn - volIbiologicalandphysicalaspects.N. Hojo,(ed.),Oxford\&IBHPublicationCo.Pvt.Ltd, NewDelhi, 2000, 7-17.

[17] T. Yamamoto, T. Miyajima, K.Mase, T.lizuka,Breeding of silkworm race'sericinhope' secretingsilkproteininwhichsericiniscontainedhighconcentration,Ann.Rep.Natl.Ins t.Agrobiol.Sci.Japan, 2002, 99-100.

[18] C.Z. Zhou,F. Confalonieri,N. Medina,Y.Zivanovic,C. Esnault, et al. Fineorganizationofbombyxmorifibroinheavychaingene, NucleicAcidsRes.28(2000), 2413-2419.

[19] M.L. Gulrajani, Sericin:Abio-moleculeofvalue.20thcongress of the international sericulturalcommission, Bangalore,India, 2005, 21-29.

[20] G. Freddi, G. Pessina,M. Tsukada,Swelling and dissolution of silk fibroin(Bombyx

[21] mori) in N- methyl morpholine N-oxide. Intl. J. Biol.Macromol.24(1999), 251-263.

[22] S. Inoue, K.Tanaka, F. Arisaka, S. Kimura, K. Ohtomo, S. Mizuno, Silk fibroin of bombyx mori is secreted, assembling a high molecular mass elementary unit consisting of $\mathrm{H}$-chain, L- chain and P25, with a 6:6:1 molar ratio, J. Biol. Chem.

275(2000), 40517-40528. 
[23] S. Inoue, T. Kanda, Imamura M, Quan GX, Kojma $\mathrm{K}$ et al. A fibroin secretion deficient silkworm mutant, Nd-sD, provides an efficient system for producing recombinant proteins, Insect Biochem. \& Mol. Biol. 35(2005), 51-90.

[24] S. Zarkoob, D.H. Reneker, R.K. Eby, S.D. Hudson, W.W. Adams, Structure and morphology of nano electrospun silk fibers, Poly. Preprints, 39(1998), 244-245.

[25] S. Zarkoob, R.K. Eby, D.H. Reneker, S.D. Hudsonb, D. Ertley, W.W. Adams, Structure and morphology of electrospun silk nanofibers, Polymer, 45(2004), 3973-3977.

[26] E. Marsano, P. Corsini, C. Arosio, A. Boschi, M. Morminoc, G. Freddi, Wet spinning of bombyx mori silk fibroin dissolved in $\mathrm{N}$-methyl morpholine $\mathrm{N}$-oxide and properties of regenerated fibres, Intl. J.f Biol. Macromol. 37(2005), 179-188.

[27] M. Yusuf, M. Shabbir, F. Mohammad, Natural colorants: Historical, processing and sustainable prospects, Natural Products and Bioprospecting, 7(1)(2017), 123-145.

[28] B.B. Aggarwal, A. Kumar, A.C. Bharti, Anticancer potential of curcumin: Preclinical and clinical studies. Anticancer Res. 23(2003), 363-398.

[29] A.C. Dweck, Natural ingredients for colouring and styling. Intl. J. Cosmetic Sci. 24(2002), 287-302.

[30] D. Grifoni, L. Bacci, G. Zipoli, G. Carreras, S. Baronti, F. Sabatini, Laboratory and outdoor assessment of uv protection offered by flax and hemp fabrics dyed with natural dyes, Photochem. \& Photobio. 85(2009), 313-320.

[31] G.W. Taylor, Natural dyes in textile applications. Rev. Prog. Coln. \& Related Topics, 16(1986), 53- 61

[32] M.L. Gulrajani, Gegumming of silk; in silk dyeing printing and finishing. Dept. Text.Tech. Indian Institute of Technology, New Delhi, 1988, 63-95.

[33] E.R. Trotman, Dyeing and chemical technology of textile Fibers, 6th edition, Eds. Edward Arnold, London, 1984, 187- 217.

[34] N. Swarna, J.J. Moses, Surface modification of polyester fabric using polyvinyl alcohol in alkaline medium, Ind. J. Fiber \& Text. Res. 37(2012), 287- 291.

[35] Y. Yang, S.M. Lee, H.S. Lee, K.H. Lee,. Recovery of silk sericin from soap-alkaline degumming solution. Intl. J. Indl. Ent. (Korean Society of Seri. Sci. 203-208.

[36] P. Vaithanomsat, V. Kitpreechavanich, Sericin separation from silk degumming waste Water, Sep. Purn. Tech. 59(2008), 129-133.

[37] S. Tokutake, Isolation of the smallest component of silk protein: Biochemistry. Biochem. J. 187(1980), 413-417.

[38] K. Komatsu, Studies on dissolution behaviors and structural characteristic of silk Sericin. Bull. Seri. Expt. Statn. 26(1975), 135-256.

[39] K. Komatsu, Recent advances in sericin research. J. Seri. Sci.Japan, 69(1980), 457- 465.

[40] S. Pervaiz, M. Aziz, Z.F. Khan, M. Najeebullah, Floral dyes: An opportunity for punjab leather industry to promote sustainable fashion development, Intl. J. Res. Advent Tech. 4(2016), $34-39$.

[41] Z.M. Win, M.M. Swe, Purification of the natural dyestuff extracted from mango bark for the application on protein fibres. World Acad. Sci. Engg. \& Tech. 22(2008), 536-540.

[42] B.C. Mohanty, K.V. Chandramauti, H.D. Naik,Natural dyeing process of India, Published by Calico Museum of Textiles, India, 1987.

[43] R. Jihad, Dyeing of silk using natural dyes extracted from local plants. Intl. J. Sci. \& Engg. Res. 5(2014), $809-817$.

[44] AATCC test method 135-1985. Color measurement of textiles: Instrumental, Technical manual of the AATCC, Research Triangle Park, USA, 2003.

[45] AATCC test method 61-1996. Color fastness to laundering: Home and Communication accelerated, Technical manual of the AATCC, Research. Triangle Park, USA, 2003.

[46] AATCC test method 16-1998. Color fastness to light, Technical Manual of the AATCC, Research Triangle Park, USA, 2003.

[47] AATCC test method 8-2007. Color fastness to crocking, Technical Manual of the AATCC, Research Triangle Park, USA, 2007. 
[48] AATCC test method 79-2010. Absorbency of textiles, Technical manual of the AATCC, Research Triangle Park, USA, 2010.

[49] AATCC test method 197 2011. Vertical wicking of textiles, Technical manual of the AATCC, Research Triangle Park, USA, 2011.

[50] ASTM - E96, Standard test methods for water vapor transmission of materials, ASTM International, 100 Barr Harbor Drive, PO Box C700 USA, 2000.

[51] ASTM - D737-2012. Standard test methods for air permeability of textile fabrics, ASTM International, 100 Barr Harbor Drive, PO Box C700, USA, 2012.

[52] D. S. Vijayan, A. Mohan, J. J. Daniel, V. Gokulnath, B. Saravanan, and P. D. Kumar, "Experimental Investigation on the Ecofriendly External Wrapping of Glass Fiber Reinforced Polymer in Concrete Columns," vol. 2021, 2021.

[53] M. Gouda, A. Hebeish, Preparation and evaluation of $\mathrm{CuO} /$ Chitosan nanocomposite for antibacterial finishing cotton fabric. J. Ind. Text. 39 (3)(2010), 203-213.

[54] Kiruthika, C., S. Lavanya Prabha, and M. Neelamegam. "Different aspects of polyester polymer concrete for sustainable construction." Materials Today: Proceedings 43 (2021): 1622-1625. 